Relations industrielles

Industrial Relations

\title{
From Theory and Research to Policy and Practice in Work and
} Employment-and Beyond?

De la théorie et de la recherche à la politique et à la pratique dans le travail et l'emploi - et au-delà?

\section{Harry Arthurs}

Volume 69, numéro 2, printemps 2014

URI : https://id.erudit.org/iderudit/1025036ar

DOI : https://doi.org/10.7202/1025036ar

Aller au sommaire du numéro

\section{Éditeur(s)}

Département des relations industrielles de l’Université Laval

\section{ISSN}

0034-379X (imprimé)

1703-8138 (numérique)

Découvrir la revue

Citer cet article

Arthurs, H. (2014). From Theory and Research to Policy and Practice in Work and Employment-and Beyond? / De la théorie et de la recherche à la politique et à la pratique dans le travail et l'emploi - et au-delà? Relations industrielles / Industrial Relations, 69(2), 423-446. https://doi.org/10.7202/1025036ar

Tous droits réservés @ C Département des relations industrielles de l’Université Laval, 2014
Ce document est protégé par la loi sur le droit d'auteur. L'utilisation des services d'Érudit (y compris la reproduction) est assujettie à sa politique d'utilisation que vous pouvez consulter en ligne.

https://apropos.erudit.org/fr/usagers/politique-dutilisation/ 


\section{From Theory and Research to Policy and Practice in Work and Employment—and Beyond?}

\section{Harry Arthurs}

The title of CIRA's 50th anniversary conference-From Theory and Research to Policy and Practice in Work and Employment-has a nostalgic ring to it. It makes us all think about "the good old days". You will recall, perhaps, that large numbers of people, who used to be known as "workers", were "employed" in something called "industry". Significant numbers of these workers joined organizations called "unions" that established collective "relations" with employers. Implausible as it now seems, governments were once so concerned about "industrial relations" (IR) that they sponsored a great deal of IR research and even conducted their own. Moreover—I am not making this up!—research sometimes led to reforms that were embedded in public "policy" or law. And though this sounds utterly improbable, some laws and policies based on research actually made things better in "practice". Or so it seemed in the good old days.

This quaint approach was epitomized by the work of the federal Task Force on Labour Relations, chaired by CIRA's first president, H.D. "Bus" Woods of McGill. The Task Force, appointed in 1966, enlisted virtually every industrial relations and labour law scholar in the country; compiled shelves-full of ambitious studies; and made scores of recommendations, a surprising number of which ended up being adopted by one or another Canadian jurisdiction. Moreover, the era of the Woods Task Force coincided, more or less, with a number of broad policy developments with IR implications including: the introduction of the Canada Pension Plan (1965), Medicare (1966) and other social welfare programs, the expansion of post-secondary education, negotiation of the Canada-US Auto Pact (1965) and adoption of other interventionist public policies designed to create jobs and enhance productivity. And finally, that same period saw numerous improvements in corporate human resources (HR) practices including the emergence of highly structured internal labour markets, increased job security, and more widespread provision of employment-related benefits such as defined benefit pensions and annual vacations. This was heady stuff for IR 
scholars who not only advocated progressive public policies, but also served as architects and administrators of progressive regulatory regimes, and proffered advice on progressive workplace practices. We believed that our research, our analysis, was changing the world.

But we were wrong. We under-estimated the historical contingency of the IR system within which we were working. That system was shaped initially by memories of the 1930s Great Depression, by the experience of wartime mobilization, by morale-raising slogans about democracy and freedom from want. But it was very much an artefact of the unique political economy of the postwar period: Keynesian economic policies, the expansion of manufacturing in response to pent-up consumer demand, the Cold War contest for the hearts and minds of workers, and the optimism engendered by two or three decades of a baby boom, relatively low unemployment, rising living standards and the fairer distribution of social goods. However, when the force of those unusual historical circumstances was spent, the IR policies and practices they had enabled entered a long period of disruption and decline.

To remind you of some painful details:

- Public interest in, knowledge of and sympathy for workers' issues diminished, while employer attitudes and government actions towards unions hardened.

- Union density, economic power and political influence all shrivelled.

- The Canadian labour market became polarized into "good" and "bad" jobs, secure and precarious jobs.

- Average wages flat-lined over considerable periods of time; average job tenure shrank; pension coverage declined; and labour laws came to protect a shrinking percentage of the workforce.

- The social safety net-including both elements provided by the State and those provided by employers-developed gaping holes.

- And in general, various fiscal, trade, economic and social policies were adopted that effectively repudiated the values and undermined the arrangements on which Canada's postwar industrial relations systems were built.

This is a rather glum reprise of recent IR History, so in the interests of both accuracy and audience morale, I will add three caveats:

First caveat: there were positive developments as well as negative ones:

- Labour markets produced winners as well as losers.

- Average household incomes did not track average wages downwards, partly because of an increase in two-income households, partly because of income supports for specific population cohorts such as the elderly.

- Some new public policies and employer practices—especially those relating to workplace discrimination and harassment—-benefited important constituencies 
of Canadian workers, such as women, racial minorities and people with disabilities.

- And for whatever it is worth—not much, in my view-the Charter now formally entrenches some rights of workers including equality and mobility rights, and freedom of assembly, association and expression.

Second caveat: the sorry state of Canadian industrial relations cannot be blamed entirely on hostile employers and unsympathetic governments:

- To some extent, the postwar collective bargaining system failed because of flaws in the design of that system and in union structures and strategies.

- To a greater extent, however, labour's waning industrial and political power reflects a long-term sociological shift in workers' primary identities, in their sense of solidarity and in their inclination towards collective action.

- And most importantly, the Canadian industrial relations system was destabilized by exogenous developments—by a technological revolution, by globalization and by consequent fundamental changes in the architecture of capitalist economies.

And a third caveat: though worker-employer relations and labour market outcomes have become increasingly dire, IR research has actually become quite impressive. Not to overstate, CIRA members today are apparently able to scrutinize complex and obscure workplace phenomena with x-ray vision, to leap national and disciplinary borders in a single bound and to engage with emerging policy domains and employment practices faster than a speeding bullet. I am not sure what metrics one would use to measure improvements in IR research over the past 50 years but_-if the term is defined broadly—-there is clearly more of it today and it is generally more sophisticated.

So: if IR is getting worse and IR research is getting better, we have to ask: "what is the relationship between the two?" Or to rephrase the question: "does this mean that IR research is having less impact on policy and practice than it used to-or more?"

I will address that question in several ways. The first is to revisit my earlier suggestion that the sixties were the "good old days" of IR research, that governments back then embraced relatively progressive industrial relations and social policies and that employers adopted somewhat more enlightened HR practices. Those things were all more-or-less true, but perhaps they were not causally related. Perhaps there were influences other than good research that produced improvements in policy and practice. Remember: union density was higher in the 1960s; strikes were much more frequent; and labour's political leverage and social influence were on the rise. It is likely, then, that governments adopted progressive IR policies not because the Woods Report showed them a 
"better way" but in order to dampen down labour militancy at the polls and on picket lines. And it is likely that employers introduced more enlightened workplace practices not because they read our learned publications but because they wanted to deflect or de-radicalize unionization and ambitious projects of statutory regulation. In support of this hypothesis, I will observe only that now that times have changed, now that unions are in steep decline, neither governments nor employers have any reason to persevere with the relatively progressive policies they once embraced. Nor do they any longer do so.

My second answer is rather different. In a 2007 article, Morley Gunderson asked under what conditions IR research is likely to influence public policy. ${ }^{2}$ Apart from the quality of the research and the reputation of the researcher, he concluded, "timeliness" and "political acceptability" are key predictors of success. In other words, research may have influence-but only when researchers make recommendations that square with the government's ideological predilections or political imperatives. To revisit my analysis of the sixties, IR scholars generally adopted a social justice perspective. This is hardly surprising: from its inception as a discipline, IR was closely associated with the British Fabians and the American Progressive movement. ${ }^{3}$ The ultimate point of labour law and policy, most of us believed, was to ensure that workers were treated fairly. Fairness could be achieved in several ways: by legislating fair labour standards; by facilitating the aggregation of countervailing power and promoting collective bargaining; by having the state buffer workers against the consequences of unemployment, illness and old age; even by persuading employers to harken to their better angels. But fairness was the end in view. We were all "progressives" then. ${ }^{4}$

In the postwar period, from 1945 right through the 1960s, this view of IR still had some traction. It was, in Gunderson's terms, "timely" and "politically acceptable". However, by the1970s we had entered what the historian, Daniel Rodgers, calls "the age of fracture" about markets, power, race and gender and about IR policies and practices that are rooted in that thinking. Research that is "timely" or "politically acceptable" today-post-fracture-valorizes markets and promotes greater entrepreneurial freedom, less regulation and a reduced safety net. To state my position clearly, my concern is not that such research has had more attention than its scholarly merit warrants; on the contrary, it is often highly erudite and deserves attention. Rather I am making the same point that Gunderson did: scholarly merits aside, IR research can be highly influential, precisely because it tells employer-friendly governments and worker-unfriendly employers just what they want to hear.

Of course governments would generally prefer to hear nothing at all about industrial relations. Many of them have disbanded their labour ministries or parked them under the umbrella of larger ministries concerned with economic 
growth or social welfare. As a result, labour policy often emerges as a by-product of fiscal, monetary, trade or welfare policy. Worse yet, governments are able to do this because no one seems to care. Few, if any, newspapers have a labour reporter; labour issues have virtually disappeared from popular culture and public consciousness; and workers have ceased to think of themselves in terms of their class identity or collective interests. ${ }^{6}$

Now to expand Gunderson's thesis: IR research is likely to be influential, I will argue, not only when it is politically acceptable, but also when it is intellectually fashionable. Intellectual fashions in our discipline have changed considerably since the 1960s. As a study of IR research reported in 2000, there has been a decided shift from "inductive, qualitative and policy-oriented research" to "deductive, quantitative and discipline-oriented research". ${ }^{7}$ There are reasons for that shift, which have to do both with ideology and with intellectual trends. However, I want to focus on consequences rather than causes. People who do "discipline-oriented" research-whether their discipline is macro-economics, gender studies or constitutional law-have brought energy, breadth and depth to IR scholarship. However they tend, naturally enough, to deploy theories and methodologies associated with their "home" discipline, and to measure their academic legitimacy according to that discipline's particular metrics.

The result has been to shift the centre of gravity within IR scholarship and to diffuse its focus. First example: mainstream economists writing about labour issues are likely to generate models designed to demonstrate how efficient outcomes are achieved or impeded in hypothetical markets. They are unlikely to adopt the older approach of IR scholars, who typically dealt with granular or impressionistic data, who were wary of models and who sought to reverse or modify market outcomes, not replicate or reinforce them. Second example: Charter scholars writing on workers" "rights" are likely to adopt the binary analysis of jurists-rights exist or not; they are respected or not. And they are likely to focus more on the formal outcome of individual cases than on their actual impact on relationships and systems. This is in sharp contrast to the traditional tolerance of IR scholars for conflict and ambiguity, and their search for equilibrium and compromise. In short, because discipline-focussed IR scholars naturally tend to adopt the conventional wisdom of their home disciplines and to speak in their distinctive vernaculars, they often end up facing at right angles to the assumptions, values and discourses that once characterized much of IR research.

This shift to "discipline-oriented" research signals not merely a natural evolution in scholarly theorizing and methodology. It stems from and reinforces a significant trend towards embedding IR units within business schools, rebranding them as departments or research centres concerned with Human 
Resources Management (HRM), Personnel Management (PM) or Organizational Behaviour (OB). Over time, in this new institutional context, and as personnel change, scholars in the field are likely to attenuate or abandon their ties to the "old" IR discipline, acquire a different cohort of "significant others", proceed from a different set of implicit assumptions about employment relations and labour markets, identify different priorities for research and different venues for publication and, for all these reasons, gradually infuse their work with a different, business-friendly ideology. To be sure, a countervailing trend has also developed: to re-constitute IR programs under the generic rubric of Work and Labour Studies (a new Canadian learned society has adopted that title) ${ }^{8}$ in which both pluralist and critical analyses of $I R$ issues can find a place; but this is a more modest trend.

To sum up my argument crudely but succinctly: IR research inevitably has an ideological tendency; it is most likely to be influential when that tendency aligns with the dominant social and political forces of the time. And IR research has a disciplinary pedigree or provenance; it is most likely to be accorded academic respect when it faithfully conforms to the expectations and conventions of its discipline of origin. Thus, if we are looking to influence government policy or corporate practice, if we are looking to make ourselves useful as practitioners or consultants, if we are looking to make our fame and fortune in our "home" disciplines, we know what to do. We must abandon the old "progressive" tendency in IR research, find a way to ingratiate ourselves with influential people in ministries such as Trade or Finance, and hone our skills as macro-economists or constitutional lawyers.

But let us remember where we stand at this moment in history. Global capitalism is in considerable disarray. Markets and economies are in trouble; companies and governments are in trouble; transnational and national institutions are in trouble; IR systems are in trouble; disciplines like ours are in trouble. They are all in trouble because they cannot, will not or do not offer any way forward except those based on the same thinking that brought us to our present difficulties.

Worst of all, people are in trouble. Conditions have been deteriorating for some time for employed workers in many developed economies in all the ways I mentioned earlier. But remember: they have been deteriorating as well for a long list of other people: for young people and members of marginalized communities who can find only precarious employment or none at all; for older people who cannot afford to retire or have been forced out of the labour market with no prospects of re-entry or of proper pensions; for people who have maxed out their credit cards or are behind on their mortgages or their rent; for self-employed people and those who own farms or taxis or franchised small businesses; for people in the informal economy or on the dole. 
Many of these people have devised short-term survival strategies within their local communities; but some have surrendered to despair, some have embraced xenophobic or authoritarian fantasies, and some have joined protest movements like the Indignants or Occupy Wall Street that have, alas, failed to propose coherent programs or to demonstrate that they have staying power. The picture is not so different from what it was in the 1890s or 1930s_decades marked by economic chaos, social turmoil and political unrest. And remember: it was chaos, turmoil and unrest that gave practical purpose and moral imperative to industrial relations not only as an academic discipline and as a profession but also as a plausible, if partial, response to what used to be called "the social question".

So we are back where we started. We can continue to provide research that is "timely", "politically acceptable" and intellectually fashionable, research that demonstrates the inevitability and desirability of current policy and practice, research - in other words - that is likely to be influential in the corridors of governmental and academic power. Or as we once did, we can generate the kind of research that the historical moment requires: research that challenges, research that tells inconvenient truths about policies and practices that are not working, research that exposes assumptions and structures that are entrenching inequality and legitimating social dysfunction, research that breaks taboos about what is corporate "best practice" or "realistic" public policy, research that raises the normative questions that are so often absent from orthodox theorizing and dominant methodologies.

While it would represent a significant departure from present trends, and is unlikely to be influential in the short term, I do not think of that kind of research as "radical", unless you think of the Webbs or John R Commons or Bus Woods as radicals. I think of it as the legitimate and necessary application of lessons learned in a discipline that, after all, helped to invent and give institutional form to collective bargaining, labour standards, social security, professional HR management and new techniques of dispute resolution-inventions that, despite their shortcomings, represented the most sustained and successful attempts so far to humanize capitalism without destroying it. Industrial relations scholars and practitioners are therefore almost uniquely equipped to provide States, social movements and corporations with what they most need: a sophisticated analysis of social and economic relations, a repertoire of credible strategies to manage those relations and the technical know-how needed to translate those strategies into practice.

What I propose, then, is that we invest our accumulated intellectual capital in addressing contemporary controversies that bear a striking resemblance to the classical issues of industrial relations. Stripped down to bare bones, here are some of the insights of IR that may be generalizable: 
- Markets do not automatically correct entrenched asymmetries of wealth and power: they often reinforce them-with fairly dire long-term social consequences. Countervailing power, whether mobilized by the State or by social forces, is necessary in order to avoid those asymmetries or mitigate their consequences.

- However, the decline of postwar IR regimes over the past four or five decades has taught us that the forces that shape, regulate and destabilize such regimes are complex and inter-connected. Consequently, we have to learn to think about countervailing power in more general terms than we have been doing. Indeed, we have to engage in a more general and fundamental discussion of the source and nature of power. That is why I stress the importance of thinking about all the people suffering in the present crisis, not just employed workers and about all the public policies and corporate practices that affect those people, not just policies and practices that fall within the traditional scope of our discipline.

- If we broaden our "clientele" and the scope of our policy concerns, we must also broaden the mandate of our discipline. We should constitute ourselves as the vanguard of a new academic discipline that, for want of a better descriptor, I will call the Study of Relations of Economic Power and Resistance. ${ }^{9}$

- We might begin that broadening process by offering others access to our extensive knowledge of how to conceptualize, design and implement intervention in labour markets. There are precedents for this. IR scholars designed much of Roosevelt's National Industrial Recovery Act and its Canadian counterparts. They also lent their expertise to the civil rights movement of the 1960s and to attempts to organize and empower welfare recipients, contributed to the women's movement and the environmental movement, and helped to shape the way we deal with human rights complaints and create fairer governance arrangements for aboriginal peoples. Surely, if we put our minds to it, we can do the same for tenants and mortgagors, farmers and consumers, the self-employed and small businesses.

Obviously, there are concerns. How credible is our learning and our advice, given that the IR system we created is in disarray? How exportable are the lessons of IR given that one of those lessons is that systems of countervailing power tend to be situation-specific and time-limited? Is any serious resistance to economic power likely to be tolerated in a political economy that is deeply, almost constitutionally, committed to the primacy of markets? Can we and should we replicate national systems of labour market regulation in a global economy that lacks effective norm-generating or norm-enforcing institutions?

These are legitimate questions to which I have only very general responses. The first response is of course that we can learn from our failures as well as our 
successes: not allowing disciplinary and mandate boundaries to circumscribe our analysis is perhaps the most important lesson we must learn. The second is that I am not proposing that we export anything from IR to our new discipline except some very general ideas about how to overcome problems that are common to most systems of countervailing power. The third is that I am not proposing that we do away with markets-only that we acknowledge their negative effects and work diligently to limit, ameliorate or eradicate those effects. And finally, I am not proposing that we replicate anything; I urge only that having several times invented or re-invented a system of countervailing power, we know a thing or two about how to do that, even "without the State", if needs be.

And I offer one more response to sceptics and to critics of the idea that IR can reinvent itself as the study of economic power and resistance. The IR community confronts two choices. Choice one: same-old, same-old. We can keep inventing clever ways to bring old regimes of workplace regulation into line with new labour market realities; we can continue to explain to employers why treating workers with greater consideration and respect is in their own interest; we can persist with whispering sweet Charter nothings in the ear of power and hope that power is in a mood to be seduced. However, I am afraid that each of these strategies will turn out to be an exercise in futility, though I suppose we will have to persevere with all of them for the time being, faute de mieux.

Or choice two: we can search diligently for genuine alternatives to our present dysfunctional system. We can accept that IR as a discipline and profession, as a distinct domain of public policy and approach to class relations has arrived in a cul-de-sac. We are here partly because of exogenous circumstances, partly because of our own shortcomings. But we are most definitely here. Where do we go next?

The first move, as I have just suggested, is to shift our frame of reference, to make it more open-ended and inclusive: to re-invent ourselves as the Canadian Association for the Study of Economic Power and Resistance. From that initial move, a number of developments might follow. First, we are likely to find ourselves engaged with a new group of colleagues whose frames of reference differ from ours, though they deal with very similar questions. Attempts to negotiate the differences in our intellectual traditions and in the historical experiences that frame up our respective disciplines are likely to prove intellectually fruitful for all parties. Second, we will have to address a broader, though related, set of policy challenges. At a moment when industrial relations seem to have reached an impasse, these new challenges just might re-energize our discipline, give it a new lease on life. And third, we will have to engage with a new "clientele" - a different set of relationships to study, a different audience to which to direct our findings. If we can help that new clientele to understand how unequal power af- 
fects their lives, and if we can propose fair and practical responses to the abuses of power they are experiencing, conceivably we will enhance both the reputation of our discipline and its social utility.

Note: I have said nothing so far about gaining influence, nothing about how in our new incarnation we might be able to nudge governments and businesses towards greater fairness in economic relations across broad swathes of the economy. To be honest, it is highly unlikely that governments that have undermined countervailing power for workers will support countervailing power for farmers. It is improbable that governments that have allowed labour standards to deteriorate in our workplaces will enact or enforce legislation to protect tenants or consumers. And in the current financial situation, it is almost unthinkable that governments that have been cutting access to El will invest in pensions or drug plans. In short, however compelling our evidence; however sound our recommendations, as things stand today if our research demonstrates that markets have failed us and that market outcomes must be managed in the public interest, it is likely to be ignored.

But once again, I reach back into the history of industrial relations. Research can become influential; Daniel Rodgers assures us, if "the intellectual economy of catastrophe" brings old ideas and institutions into disrepute and creates an appetite for new ideas and structures. ${ }^{10}$ As he points out, this is precisely what happened during the Great Depression, when forty years of research by John Commons and others-previously ignored in mainstream America-suddenly became indispensable. The architects of the New Deal used these studies (according to Rodgers) as a template to develop an array of urgent reforms not only in industrial relations but across the whole of America's wrecked economy. The Fabian architects of the British Welfare State did something similar in 1945. Morley Gunderson reminded us that the timeliness of research helps to determine its influence, and he was right. But what he did not mention is that timeliness is a ticking clock and influence therefore a moving target. Ideas are most likely to be influential in the short term if they are an easy sell, if they reinforce the conventional wisdom, slap fresh paint on clapped-out public policies and give aid and comfort to the powerful. But ideas are most likely to be influential in the long term if they do the opposite: if they force scholars and professionals to rethink their long-held views, show hard-pressed governments how they can make a constructive new start and remind those with power that if they do not exercise it responsibly and fairly, they are likely to lose it.

One can make a good case that research should be driven by intellectual, social or moral imperatives, rather than by the desire for influence. But I am not making that case. I am making the case for the re-invention of IR so that it will indeed be fit for purpose at the historical moment when the need for it becomes 
both obvious and urgent. That moment might arrive tomorrow or ten or twenty years from now. But there will come a moment when we have all had enough of unstable markets, lopsided power relations, widespread unfairness and declining living standards. When that moment arrives, IR scholars who have enrolled in the new discipline of economic power and resistance will become very influential indeed-and useful as well.

\section{Notes}

1 Woods, H. D., Chairman. 1968. Canadian Industrial Relations: The Report of the Task Force on Labour Relations. Ottawa: Privy Council Office.

2 Gunderson, Morley. 2007. "How Academic Research Shapes Labor and Social Policy.» Journal of Labor Research, 28 (4), 573-590 at 575.

3 Redaction note: In Québec, we must also consider the influence of the European Social Catholics, as Gérard Dion, the founder of Relations industrielles/Industrial Relations, was a leading representative.

4 Hyman, Richard. 2009. "Why Industrial Relations?" What's the Point of Industrial Relations? R. Darlington, ed. Manchester: BUIRA.

5 Rodgers, Daniel. 2011. Age of Fracture. Cambridge, Massachusetts: The Belknap Press of Harvard University.

6 Arthurs, Harry. 2006. "What Immoral Hand or Eye?: Who Will Redraw the Boundaries of Labour Law.» Boundaries and Frontiers of Labour Law: Goals and Means in the Regulation of Work. In Davidov, Guy and Langille, Brian, eds. Oxford: Hart Publishing, 373-389; Arthurs, Harry. 2011. "Labour Law after Labour." The Idea of Labour Law. In Davidov, Guy and Langille, Brian, eds. Oxford: Oxford University Press, 13-29.

7 Whitfield, Keith and Strauss, George. 2000. "Methods Matter: Changes in Industrial Relations Research and their Implications." British Journal of Industrial Relations, 38 (1), 141151 at 141.

8 Canadian Association for Work and Labour Studies http://cawls.ca/en/ (accessed January 11, 2014).

9 I have developed this idea at greater length in Arthurs, Harry. 2013. "Labour Law as the Law of Economic Subordination and Resistance: A Thought Experiment." Comparative Labor Law and Policy Journal, 34, 585-604.

10 Rodgers, Daniel. 1998. Atlantic Crossings. Cambridge, Massachusetts: The Belknap Press of Harvard University at 413-416. 


\section{De la théorie et de la recherche à la politique et à la pratique dans le travail et l'emploi — et au-delà?}

\section{Harry Arthurs}

La conférence qui marque le $50^{\mathrm{e}}$ anniversaire de l'Association canadienne des relations industrielles (ACRI) porte un titre empreint de nostalgie : De la théorie et de la recherche à la politique et à la pratique dans le travail et l'emploi. En effet, il rappelle le " bon vieux temps ». Vous vous souvenez peut-être de tous ces gens qu'on appelait « travailleurs », qui étaient les « employés » de ce qu'on appelait I'« industrie ». Un grand nombre de ces travailleurs adhéraient à des organismes nommés "syndicats », chargés d'établir des " relations » collectives avec les employeurs. Aussi incroyable que cela puisse paraître, l'État se préoccupait alors des « relations industrielles » à un point tel qu'il consacrait d'importantes sommes à la recherche dans ce domaine et menait même ses propres études. D'ailleurs — et je n'invente rien! —, ces études débouchaient parfois sur des réformes enchâssées dans des "politiques » publiques ou des lois. De surcroît, certaines lois et politiques fondées sur la recherche conduisaient à des améliorations de la situation en " pratique ». Du moins, c'est ce que nous croyions à cette époque bénie.

Cette approche, aujourd'hui désuète, s'est parfaitement incarnée dans les travaux de l'Équipe spécialisée en relations du travail du gouvernement fédéral, présidée par le premier président de l'ACRI de l'époque, H.D. «Bus» Woods, de I'Université McGill '. Ce groupe de travail, créé en 1966, qui comptait dans ses rangs pour ainsi dire tous les spécialistes des relations industrielles (RI) et du droit du travail au Canada, a produit de nombreuses et ambitieuses études et a formulé des dizaines et des dizaines de recommandations, dont un nombre étonnant ont été adoptées par divers ordres de gouvernement au pays. En outre, les travaux du Groupe de travail du professeur Woods coïncidaient plus ou moins avec l'adoption d'un certain nombre de politiques importantes qui ont eu des répercussions sur les relations industrielles (RI), notamment la création du Régime de pensions du Canada (1965), du régime d'assurance-maladie (1966) et d'autres programmes d'aide sociale, l'expansion de l'enseignement postsecondaire, la négociation

Harry Arthurs, professeur émérite et président émérite, Université York. Le présent article est le texte de l'adresse inaugurale prononcée lors de la 50 Conférence annuelle de l'Association Canadienne des Relations Industrielles, le 29 mai 2013. L'auteur remercie Alex Zamfir, doctorant à l'Osgoode Hall Law School, pour son aide à la rédaction et à la recherche. 
du Pacte de l'automobile entre le Canada et les États-Unis (1965) et l'adoption d'autres politiques publiques interventionnistes visant à créer de l'emploi et à augmenter la productivité. Enfin, cette période a été le théâtre de nombreuses améliorations des pratiques en matière de ressources humaines $(\mathrm{RH})$, notamment l'apparition des marchés internes du travail très structurés, l'accroissement de la sécurité de l'emploi et la généralisation des avantages sociaux tels que les régimes de retraite à prestations déterminées et les congés annuels. C'était l'âge d'or des chercheurs en RI qui, en plus de préconiser des politiques publiques progressistes, étaient les architectes et les administrateurs de régimes réglementaires avantgardistes et prodiguaient leurs conseils sur les pratiques progressistes en milieu de travail. Nous croyions alors que nos recherches et nos analyses étaient en train de changer le monde.

Or, nous avions tort. Nous avons sous-estimé l'influence de la conjoncture historique sur le système de RI dans lequel nous œuvrions. Celui-ci avait été façonné au départ par le souvenir de la Grande Crise des années 1930, l'expérience de la mobilisation en temps de guerre et les slogans optimistes sur la démocratie et sur l'affranchissement de la misère. Mais il résultait surtout de l'économie politique unique qui caractérisait l'Après-Guerre : des politiques économiques keynésiennes, l'expansion du secteur de la fabrication pour répondre à la demande croissante de biens de consommation, la Guerre Froide opposant les grandes idéologies dans une opération de séduction auprès des travailleurs ainsi que l'optimisme engendré par deux ou trois décennies de baby-boom, un taux de chômage relativement faible, la hausse constante du niveau de vie et une répartition plus équitable des richesses collectives. Cependant, lorsque l'effet de ces circonstances exceptionnelles s'est atténué, les politiques et les pratiques de RI, qui avaient jusque-là le vent en poupe, ont entamé une longue période de perturbations et de déclin.

L'état des lieux actuel s'avère, d'ailleurs, plutôt désolant :

- L'intérêt, la connaissance et la sympathie du public à l'égard des luttes ouvrières ont diminué alors que l'attitude des employeurs et les mesures gouvernementales à l'égard des syndicats se sont durcies.

- Le taux de syndicalisation, le pouvoir économique des syndicats et leur influence politique ont rétréci comme peau de chagrin.

- Le marché du travail au Canada s'est polarisé entre les «bons » et les « mauvais » emplois, les emplois protégés et les emplois précaires.

- Les salaires moyens ont stagné durant de longues périodes, la durée moyenne d'occupation d'un emploi a diminué, la protection en matière de pensions a décliné et le pourcentage de travailleurs protégés par les lois du travail a chuté.

- Le filet social, tissé grâce à la participation de l'État et à celle des employeurs, s'est énormément affaibli. 
- De façon générale, diverses politiques fiscales, commerciales, économiques et sociales ont été adoptées à l'encontre des valeurs et des accords qui avaient servi de base aux systèmes de relations industrielles édifiés au Canada durant l'Après-Guerre.

II s'agit là d'un bien sombre tableau de l'histoire récente des RI. Aussi, tant dans un souci d'exactitude que pour remonter le moral de l'auditoire, je me dois d'y apporter trois précisions.

En premier lieu, en marge de ces aspects négatifs, il y a eu des développements positifs :

- Les marchés du travail ont produit des gagnants, en même temps que des perdants.

- Les revenus moyens des ménages n'ont pas suivi la courbe descendante des salaires moyens, en partie, grâce à l'augmentation du nombre de ménages à deux revenus, tout comme grâce au soutien du revenu offert à des groupes démographiques particuliers, notamment aux personnes âgées.

- Certaines politiques publiques et pratiques des employeurs - en particulier celles qui touchent à la discrimination et au harcèlement au travail — ont profité à certains groupes de travailleurs canadiens, notamment les femmes, les minorités ethniques et les personnes handicapées.

- Enfin, détail moins significatif à mes yeux, la Charte reconnaît aujourd'hui officiellement certains droits aux travailleurs, notamment le droit à l'égalité et à la mobilité ainsi que les libertés de réunion, d'association et d'expression.

En deuxième lieu, le pitoyable état des relations industrielles au Canada n'est pas uniquement attribuable à l'hostilité des employeurs et à l'indifférence des gouvernements :

- Dans une certaine mesure, l'échec du régime de négociation collective de I'Après-Guerre résulte de failles dans sa conception ainsi que dans les structures et les stratégies des syndicats.

- Toutefois, dans une plus large mesure, le déclin du pouvoir industriel et politique des travailleurs découle d'un changement sociologique à long terme touchant l'identité primaire des travailleurs, leur sens de la solidarité et leur propension à l'action collective.

- Par-dessus tout, le système canadien de relations industrielles s'est vu déstabilisé par des facteurs exogènes : la révolution technologique, la mondialisation et les changements fondamentaux de l'architecture des économies capitalistes qui en découlent.

En troisième et dernier lieu, alors que les relations du travail ainsi que les conditions d'emploi se dégradaient, de même que les effets du marché du travail, la recherche dans le domaine des RI a réalisé d'impressionnants progrès. On peut, 
sans exagérer, affirmer que les membres de l'ACRI aujourd'hui semblent en mesure de scruter d'un œil aiguisé les phénomènes les plus obscurs et complexes du monde du travail, de franchir d'un bond les frontières nationales et disciplinaires ainsi que d'analyser à la vitesse de l'éclair les nouvelles politiques et pratiques dans le domaine de l'emploi. J'ignore quel type d'indicateur permettrait de mesurer les améliorations de la recherche en matière de RI au cours des 50 dernières années, mais une chose est certaine : au sens large, la recherche est plus foisonnante et généralement plus sophistiquée que jamais.

Ainsi, alors que les RI se détériorent, la recherche dans ce domaine gagne en qualité. Nous avons donc à nous interroger : quelle est la relation entre ces deux phénomènes? Autrement dit : Doit-on en déduire que la recherche en RI a moins — ou plus — d'influence qu'avant sur les politiques et les pratiques ?

J'aborderai cette question sous plusieurs angles. Revenons d'abord sur mon postulat de départ : les années 1960 représentent l'âge d'or de la recherche en $\mathrm{Rl}$, les gouvernements, à cette époque, élaboraient des politiques de relations industrielles et sociales relativement progressistes, et les employeurs adoptaient des pratiques un peu plus éclairées en matière de gestion des RH. S'il y a certes un fond de vérité dans ces assertions, elles ne sont pas forcément liées par une relation de causalité. D'autres facteurs que la recherche ont peut-être contribué à l'amélioration des politiques et des pratiques. N'oublions pas que les années 1960 ont été marquées par un taux de syndicalisation plus élevé, des grèves beaucoup plus fréquentes et une montée du pouvoir politique et de l'influence sociale des travailleurs. Dans ce contexte, I'État a sans doute assoupli ses politiques de RI, non pas en réponse aux recommandations du Rapport Woods, mais bien pour apaiser les mouvements de contestation qui s'exprimaient sur les piquets de grève comme aux urnes. De la même façon, on peut supposer que les employeurs n'ont pas amélioré leurs pratiques après avoir lu nos publications savantes, mais dans le but de contrer la radicalisation des mouvements syndicaux et les ambitieux projets de réglementation. À l'appui de cette hypothèse, rappelons qu'aujourd'hui, avec le net recul du syndicalisme, l'État et le patronat n'ont plus aucune raison de poursuivre les réformes politiques relativement progressistes qu'ils avaient entamées. D'ailleurs, ils y ont mis un terme.

Ma seconde réponse s'avère d'un tout autre ordre d'idées. Rappelons que, dans un article publié en 2007, Morley Gunderson s'est intéressé aux conditions déterminant l'influence des études en RI sur la politique publique ${ }^{2}$. Outre la qualité des travaux et la réputation du chercheur, la publication des études « au moment opportun » et leur " acceptabilité politique » se révèlent des facteurs clés du succès. En d'autres termes, la recherche exerce une certaine influence - mais uniquement dans la mesure où les recommandations qui en découlent cadrent avec l'idéologie du gouvernement ou ses impératifs politiques. Revenons 
sur mon analyse des années 1960. À cette époque, les chercheurs en Rl adoptaient généralement l'angle de la justice sociale. Rien d'étonnant à cela : à ses débuts, cette discipline était étroitement associée aux Fabiens en Grande-Bretagne et au mouvement progressiste américain ${ }^{3}$. Les lois et les politiques régissant le monde du travail n'avaient pour objet, croyions-nous, que le traitement équitable des travailleurs. Une plus grande justice pouvait être atteinte par divers moyens : établir des normes du travail acceptables, faciliter l'agrégation d'un contre-pouvoir syndical et promouvoir la négociation collective, obtenir de l'État des mesures de protection des travailleurs contre les effets du chômage, de la maladie et de la vieillesse et, enfin, persuader les employeurs d'écouter la voix de leur bonne conscience. L'équité était notre but ultime. Nous étions tous progressistes à cette époque ${ }^{4}$.

Durant l'Après-Guerre, soit de 1945 jusqu'à la fin des années 1960, cette vision des RI avait encore un certain attrait. Elle était, pour paraphraser Gunderson, " opportune » et « politiquement acceptable ». Or, les années 1970 ont marqué le début de l'« ère de la fracture », ainsi nommée par I'historien Daniel Rodgers ${ }^{5}$, une période de transformation radicale de notre vision du marché, du pouvoir, des races et des sexes, ainsi que des politiques et pratiques de RI ancrées dans cette vision. Aujourd'hui, dans l'après-fracture, la recherche « opportune » ou « politiquement acceptable » valorise les marchés et préconise une plus grande liberté d'entreprise, la déréglementation et la réduction du filet social. Soyons clairs : je ne prétends pas que de telles études aient obtenu plus d'attention que ne le justifiait leur valeur scientifique; au contraire, elles sont généralement le fruit d'une grande érudition et sont dignes d'intérêt. Je me range plutôt derrière l'argument de Gunderson : quelle que soit sa valeur scientifique, la recherche en RI peut avoir une forte influence, en particulier lorsqu'elle confirme à des gouvernements favorables aux employeurs et à des employeurs défavorables aux travailleurs précisément ce qu'ils désirent entendre.

Évidemment, les gouvernements préféreraient ne jamais entendre parler de relations industrielles. Bon nombre d'entre eux ont démantelé leurs ministères du Travail ou les ont placés sous l'égide de grands ministères qui se préoccupent de croissance économique ou d'aide sociale. Résultat, les politiques en matière de travail sont généralement subordonnées à des politiques fiscales, financières, commerciales ou d'aide sociale. Pire encore, comme personne ne semble s'en soucier, l'État a toute liberté d'agir. Rares sont les quotidiens qui ont encore un journaliste spécialisé sur les questions du travail; celles-ci ont pour ainsi dire disparu de la culture populaire et de la conscience publique, et les travailleurs ne se voient plus comme une classe sociale défendant des intérêts collectifs ${ }^{6}$.

J'irais même plus loin que Gunderson : la recherche en RI, à mon sens, n'est pas seulement influente lorsqu'elle est politiquement acceptable, mais aussi 
lorsqu'elle s'inscrit dans le courant intellectuel à la mode. Dans notre discipline, les écoles de pensée ont considérablement changé depuis les années 1960. Comme I'indiquait une étude de 2000 sur la recherche en RI, il y a eu un rejet délibéré de la « recherche inductive, qualitative et axée sur les politiques » au profit de la " recherche déductive, quantitative et axée sur la discipline $»^{7}$. Les raisons de ce changement relèvent à la fois de l'idéologie et de courants intellectuels. Toutefois, je m'intéresse davantage à ses conséquences qu'à ses causes. Les chercheurs " axés sur leur discipline »-qu'il s'agisse de macro-économie, d'études sur les rapports sociaux entre les sexes ou de droit constitutionnel — ont redynamisé, élargi et approfondi le champ d'études des RI. Or, ils ont une tendance naturelle à échafauder des théories et des méthodes associées à leur discipline, puis à mesurer leur légitimité à l'aune des critères qui lui sont propres.

Ce changement a eu pour effet de déplacer le centre de gravité à l'intérieur du champ d'études des Rl et de fragmenter son objet. Prenons un exemple : les économistes de l'école dominante qui s'intéressent au monde du travail créeront probablement des modèles en vue d'expliquer pourquoi les résultats visés sont atteints ou non dans des marchés hypothétiques. II est peu probable qu'ils adoptent l'ancienne approche des chercheurs en RI, qui se fondaient généralement sur des données lacunaires ou impressionnistes, se méfiaient des modèles et cherchaient à renverser ou à modifier les effets du marché, et non à les reproduire ni à les renforcer. Prenons un autre exemple : les chercheurs qui ont comme objet la Charte et qui étudient les droits des travailleurs sont susceptibles d'adopter la vision binaire des juristes : les droits existent ou non; ils sont respectés ou non. Et, sans doute, ils s'intéresseront davantage à l'issue de cas individuels qu'à leurs répercussions réelles sur les relations et les systèmes. Ceci s'avère en opposition nette à la tolérance traditionnelle des chercheurs en RI face aux conflits et aux ambiguïtés, ainsi qu'à leur recherche de l'équilibre et du compromis. En somme, étant donné que les chercheurs en Rl, axés sur une discipline, tendent naturellement à adopter les principes conventionnels de leur champ d'études et à employer un jargon distinctif, ils présentent souvent un point de vue opposé aux hypothèses, aux valeurs et aux discours caractéristiques de la recherche en RI.

Ce virage au profit de la recherche " axée sur une discipline » ne traduit pas une simple évolution naturelle de la théorisation et de la méthodologie scientifiques. II résulte d'une tendance de plus en plus répandue à intégrer les unités de RI aux Écoles de commerce, en les rebaptisant Département ou Centre de recherche en gestion des ressources humaines $(G R H)$, en gestion du personnel ou en comportement organisationnel. Dans ce nouveau contexte institutionnel et comme le personnel se renouvelle également, les chercheurs en RI vont, sans doute, négliger ou abandonner leur attachement à leur ancienne discipline pour acquérir une série d'autres disciplines, partir d'hypothèses différentes sur les 
relations d'emploi et le marché du travail, modifier leurs priorités en matière de recherche et trouver de nouvelles avenues de publication et, par conséquent, insuffler graduellement à leurs travaux une idéologie différente, favorable aux entreprises. Certes, une tendance compensatrice a vu le jour : la reconstitution des programmes de RI sous la bannière générique des études du travail et du syndicalisme (une nouvelle société savante canadienne a, d'ailleurs, choisi ce nom) ${ }^{8}$, qui encourage à la fois les analyses pluralistes et critiques des questions de RI, mais cette tendance demeure encore modeste.

Résumons notre argument en quelques mots : la recherche en RI est inévitablement associée à une idéologie et elle a une meilleure force de conviction lorsqu'elle s'accorde avec les courants politiques et sociaux dominants. Elle est, en outre, liée à sa provenance, c'est-à-dire à sa discipline d'origine, et elle est généralement mieux accueillie dans les milieux universitaires lorsqu'elle se conforme fidèlement aux attentes et aux conventions de celle-ci. Ainsi, si nous souhaitons influencer les politiques publiques ou les pratiques des entreprises, si nous voulons nous rendre utiles à titre de spécialistes ou de consultants, si nous cherchons la célébrité et la fortune en tant qu'experts dans notre discipline d'origine, voilà ce que nous devons faire : abandonner l'ancienne tendance progressiste de la recherche en $\mathrm{Rl}$, rentrer dans les bonnes grâces des personnes influentes dans les ministères, notamment ceux du Commerce ou des Finances, et affiner nos compétences en macro-économie ou en droit constitutionnel.

Mais ne perdons pas de vue la situation actuelle. Le capitalisme mondial est en déroute. Les marchés et les économies sont en crise; les entreprises, les gouvernements, les sociétés nationales et multinationales, les systèmes de RI et les disciplines comme la nôtre sont en crise, et ce, parce que tous ces acteurs sont incapables ou refusent de proposer une avenue différente de celle qui se fonde sur la pensée à l'origine de la crise.

Pire encore, la société civile est en crise. Les conditions de vie des travailleurs se sont détériorées dans de nombreux pays développés, comme nous l'avons indiqué plus haut. Or, les employés ne sont pas les seules victimes de la crise : les jeunes, les membres de communautés marginalisées qui ne peuvent espérer que des emplois précaires, les personnes âgées qui ne peuvent se permettre de prendre leur retraite ou qui ont été évincées du marché du travail sans espoir de réintégration ni de pension digne de ce nom, les personnes qui ont atteint leur limite de crédit ou qui sont incapables de rembourser leur prêt hypothécaire ou de payer leur loyer, les travailleurs indépendants et ceux qui exploitent une ferme, un taxi ou une petite franchise, les gens qui participent à l'économie informelle, les chômeurs. Toutes ces personnes logent à la même enseigne.

Bon nombre de ces personnes ont mis en œuvre des stratégies de survie à court terme dans leurs collectivités locales, mais d'autres ont cédé au déses- 
poir, certaines se sont raccrochées à des idéologies xénophobes ou autoritaires, d'autres encore se sont joints à des mouvements de protestation comme les " Indignés » ou « Occupons Wall Street » qui n'ont pas su, hélas!, proposer de programme cohérent ni démontrer qu'ils représentaient un pouvoir durable. La situation n'est pas si différente de celle des années 1890 ou 1930 - deux périodes marquées par le chaos économique, les troubles sociaux et l'agitation politique. N'oublions pas que ce sont précisément le chaos, les troubles et l'agitation qui ont donné un but concret et une obligation morale aux relations industrielles en tant que discipline et profession, mais aussi comme réponse plausible, bien que partielle, à la « question sociale».

Nous voilà donc de retour à la case départ. Nous pouvons continuer de produire des études " opportunes », " politiquement acceptables » et conformes aux courants intellectuels à la mode, qui confirment le caractère incontournable et le bien-fondé des politiques et pratiques en vigueur, autrement dit, des études ayant un pouvoir d'influence dans les corridors du Parlement et des universités. Mais nous pouvons aussi, comme par le passé, produire le type d'études qu'exige le contexte historique : des remises en question, des vérités qui dérangent à propos des politiques et des pratiques inefficaces, des études qui dénoncent les hypothèses et les structures qui engendrent les inégalités et qui légitiment le dysfonctionnement social, des études qui brisent les tabous sur les prétendues " pratiques exemplaires » ou politiques publiques « réalistes », des études, enfin, qui soulèvent les questions normatives trop souvent absentes des théories orthodoxes et des méthodes dominantes.

Certes, un tel changement rompt totalement avec les tendances actuelles et a peu de chances d'exercer une influence à court terme, mais ce type de recherche n'a selon moi rien de "radical », sauf bien sûr si I'on considère les Webbs, John R. Commons ou "Bus » Woods comme des radicaux. II s'agit plutôt de l'application légitime et nécessaire des leçons apprises dans une discipline qui, après tout, a contribué à l'invention et à l'institutionnalisation de la négociation collective, des normes de travail, de la sécurité sociale, de la gestion professionnelle des $\mathrm{RH}$ et des nouvelles techniques de résolution des conflits - autant d'innovations qui, malgré leurs défauts, ont permis d'accomplir des progrès durables ayant eu pour effet d'humaniser le capitalisme sans le détruire. Les chercheurs et les spécialistes en relations industrielles sont les mieux outillés pour offrir aux États, aux mouvements sociaux et aux entreprises ce dont ils ont le plus besoin, à savoir une analyse approfondie des relations socio-économiques, un répertoire de stratégies fiables de gestion de ces relations et le savoir-faire technique pour mettre en pratique ces stratégies.

Ma proposition est simple : employer le capital intellectuel accumulé à résoudre les controverses actuelles qui font écho aux enjeux classiques des relations 
industrielles. Ramenées à l'essentiel, voici quelques-unes des intuitions initiales des RI qui pourraient être généralisables :

- Les marchés ne redressent pas automatiquement la répartition asymétrique des richesses et du pouvoir, ils ont plutôt tendance à creuser les écarts - avec des conséquences sociales désastreuses à long terme. Le pouvoir compensateur, qu'il soit mobilisé par l'État ou par les forces sociales, est alors essentiel pour combler ces écarts ou atténuer leurs conséquences.

- Or, le déclin, au cours des quatre ou cinq dernières décennies, des régimes de RI de I'Après-Guerre, nous a enseigné que les forces qui façonnent, régulent et déstabilisent de tels régimes sont complexes et interconnectées. Par conséquent, nous devons aborder les pouvoirs compensateurs ou contrepouvoirs sous un angle plus large qu'auparavant. En fait, il est temps d'amorcer un débat plus général et fondamental sur la source et la nature de ce pouvoir. Voilà pourquoi j'insiste sur l'importance de tenir compte de toutes les victimes de la crise actuelle, et non pas seulement des employés, et de remettre en cause toutes les politiques publiques et les pratiques d'entreprise influant sur ces personnes, ce qui implique de sortir du cadre de recherche habituel de notre discipline.

- Si nous élargissons notre « clientèle » et la portée de notre réflexion sur les politiques, il nous faut aussi élargir le mandat de notre discipline. Nous devons être les pionniers d'une nouvelle discipline que je nommerai provisoirement Étude des relations entre le pouvoir économique et la résistance ${ }^{9}$.

- Nous pourrions amorcer ce processus d'élargissement en donnant à d'autres acteurs l'accès à notre connaissance étendue des méthodes de conception, d'élaboration et de mise en œuvre de mesures d'intervention dans les marchés du travail. L'idée n'est pas nouvelle : les chercheurs en RI sont les principaux architectes de la National Industrial Recovery Act adoptée sous Roosevelt dans les années 1930 et par son homologue canadien ensuite. Ils ont également prêté leur expertise au mouvement pour les droits civils dans les années 1960 et aux initiatives visant à créer des organismes de défense des assistés sociaux; ils ont participé à l'émancipation des femmes et au mouvement écologiste; ils ont aidé à définir les procédures de traitement des plaintes relatives aux droits de la personne et à concevoir des accords de gouvernance plus équitables pour les Premières Nations. Avec un peu de volonté, nous pouvons assurément en faire tout autant pour les locataires et les débiteurs d'hypothèques, les agriculteurs et les consommateurs, les travailleurs indépendants et les petites entreprises.

Évidemment, ces idées soulèvent des objections. Quel mérite peut-on accorder à nos enseignements et à nos conseils, alors que le système de RI que nous avons créé est en déroute? Comment exporter nos leçons, alors que l'une d'entre elles 
énonce que les systèmes de pouvoirs compensateurs sont généralement associés à des situations spécifiques et qu'ils sont également bien circonscrits dans le temps? Une économie politique solidement ancrée dans le principe de la suprématie des marchés tolérerait-elle la moindre forme de résistance au pouvoir économique? Pourrions-nous et devrions-nous reproduire les systèmes nationaux de réglementation du marché du travail dans une économie mondiale dénuée d'institutions chargées d'établir et de faire respecter les normes?

À ces questions légitimes, je ne peux qu'ébaucher de vagues réponses. En premier lieu, nous pouvons bien sûr apprendre de nos échecs comme de nos réussites : nous devons par-dessus tout éviter de laisser les frontières des disciplines et des mandats circonscrire notre analyse. En deuxième lieu, je ne propose pas d'exporter des éléments des RI vers notre nouvelle discipline, si ce n'est quelques idées générales sur les moyens de surmonter les problèmes communs à la plupart des systèmes de pouvoir compensateur. En troisième lieu, je ne plaide pas pour l'élimination des marchés, mais pour une prise de conscience de leurs effets néfastes et une vigilance constante en vue de limiter, d'améliorer ou d'éradiquer ces effets. En dernier lieu, il ne s'agit pas de reproduire quoi que ce soit; j'estime simplement qu'après avoir inventé et réinventé à plusieurs reprises un système de pouvoirs compensateurs, nous avons acquis une certaine expertise et sommes en mesure de le faire, même sans le « concours de l'État », s'il le faut.

J'ajouterai un dernier point à l'intention des plus sceptiques et critiques à l'égard de la capacité des Rl à se renouveler sous la forme d'études du pouvoir économique et de la résistance. La communauté professionnelle fait face à deux choix. Première option : le statu quo. Nous pouvons inventer des moyens toujours plus astucieux d'adapter les anciens régimes de réglementation du travail aux nouvelles réalités du marché. Continuer d'expliquer aux employeurs qu'ils ont tout intérêt à traiter leurs employés avec plus d'égards et de respect. Persister à murmurer des mots doux à l'oreille des décideurs dans l'espoir qu'ils se laissent séduire. Cependant, je crains qu'aucune de ces stratégies ne porte ses fruits, mais que nous soyons pour l'instant contraints de poursuivre dans cette direction, faute de mieux ${ }^{10}$.

Seconde option : chercher avec zèle d'authentiques solutions de rechange aux dysfonctionnements de notre système actuel. Reconnaître que les RI, en tant que discipline et profession, domaine distinct de politique publique et approche des relations entre les classes, sont parvenues à un cul-de-sac ${ }^{11}$. En partie à cause de circonstances extérieures, en partie à cause de nos propres échecs, peu importe : nous sommes indéniablement dans l'impasse. Quelle direction prendre maintenant?

D'abord, comme je l'ai déjà suggéré, nous devons nous doter d'un cadre de référence plus ouvert et inclusif : faire peau neuve en créant l'Association 
canadienne des études du pouvoir économique et de la résistance. Ce premier pas pourrait ouvrir la voie à diverses innovations. D'abord, nous pourrions alors engager le dialogue avec un nouveau groupe de collègues dont le cadre de référence diffère du nôtre, même s'ils s'occupent de questions similaires. Cette collaboration pourrait susciter des débats intellectuellement stimulants autour des points de vue traditionnels et des expériences antérieures qui ont façonné nos disciplines respectives. Ensuite, nous devrons faire face à un éventail élargi de défis politiques reliés entre eux. Alors que les relations industrielles semblent dans l'impasse, ces nouveaux défis pourraient bien redynamiser notre discipline, lui donner un second souffle. Enfin, nous devrons nous adapter à une nouvelle « clientèle » - des relations différentes à étudier, un nouveau public à qui faire part de nos constatations. Si nous pouvons amener cette nouvelle clientèle à reconnaître les effets des inégalités de pouvoir sur leurs vies, et si nous pouvons offrir des solutions justes et pratiques aux abus de pouvoir dont ils sont victimes, nous serons en mesure de rehausser la réputation de notre discipline et son utilité sociale.

Vous remarquerez que je n'ai pas encore abordé la question de l'influence et de la force de conviction que nous pourrons, après notre métamorphose, exercer sur les gouvernements et les entreprises, en vue d'établir des relations économiques plus équitables dans de larges pans de l'économie. En toute honnêteté, il est peu probable que les gouvernements qui ont miné le pouvoir compensateur des travailleurs soutiennent celui des agriculteurs. II est invraisemblable que les autorités publiques, qui ont laissé les normes du travail se détériorer, adoptent des lois en vue de protéger les locataires ou les consommateurs. Et dans le contexte financier actuel, il est pratiquement impensable que les gouvernements ayant limité I'accès à l'assurance-emploi investissent dans des régimes de retraite ou d'assurance médicaments. Bref, malgré les faits incontestables et la sagesse de nos recommandations, si nos études démontrent que les marchés se sont joués de nous et que leurs effets doivent être gérés dans l'intérêt du public, elles risquent de rester lettre morte.

Revenons une fois de plus à I'histoire des relations industrielles. Daniel Rodgers nous assure que la recherche peut influer sur les décisions si « l'économie intellectuelle de la catastrophe » jette le discrédit sur les anciennes idées et institutions, créant un besoin de nouvelles idées et structures ${ }^{12}$. II rappelle que c'est précisément ce qui s'est produit durant la Grande Crise des années 1930 : les travaux réalisés depuis quarante ans par John Commons et d'autres chercheurs, jusque-là ignorés par l'Amérique moyenne, sont tout à coup devenus indispensables. Ces études ont servi de modèles aux architectes du New Deal (selon Rodgers) dans la conception d'un éventail de réformes urgentes touchant non seulement le domaine des relations industrielles, mais l'ensemble de l'économie américaine dévastée. Les architectes "fabiens" de l'État-providence britannique ont procédé 
de façon similaire en 1945. Morley Gunderson nous a rappelé, avec raison, que l'opportunité de la recherche détermine en partie son influence. Mais il a oublié de préciser que l'opportunité est un facteur temporel, et que l'influence varie donc dans le temps. Les idées ont plus de chances d'influer sur les décisions à court terme si elles sont convaincantes, si elles confirment les principes conventionnels, si elles rafraîchissent les politiques publiques périmées et confortent ceux qui tiennent les rênes du pouvoir. Mais elles ont une plus grande force de conviction à long terme lorsqu'elles ont l'effet opposé, c'est-à-dire qu'elles obligent les chercheurs et les professionnels à remettre en question leurs points de vue, qu'elles montrent aux gouvernements soumis à une forte pression comment repartir sur de nouvelles bases et qu'elles rappellent aux puissants de ce monde qu'ils risquent de se voir déchus s'ils n'exercent pas leur pouvoir de manière juste et responsable.

Certes, la recherche doit reposer sur des motivations d'ordre intellectuel, social ou moral, et non sur le désir d'influence. Mais ce n'est pas la base de mon argumentation. Je plaide pour une transformation des RI afin que nous soyons prêts au moment historique où l'on en aura un besoin flagrant et pressant. II se produira peut-être demain, peut-être dans dix ou vingt ans. Mais un jour viendra où nous en aurons assez des marchés instables, des rapports de force disproportionnés, des injustices généralisées et du déclin du niveau de vie. Ce jour-là, les chercheurs en RI qui auront fait le saut vers la nouvelle discipline axée sur le pouvoir économique et la résistance devraient devenir très influents — mais aussi véritablement utiles.

\section{Notes}

1 Woods, H. D., président. 1968. Relations de travail au Canada: Rapport de l'Équipe spécialisée en relations de travail, Ottawa, Bureau du Conseil privé.

2 Gunderson, Morley. 2007. "How Academic Research Shapes Labor and Social Policy ", Journal of Labor Research, 28 (4), p. 573-590. Voir p. 575.

3 Note de la direction: Au Québec, il faut aussi parler de l'influence des catholiques sociaux d'Europe, dont Gérard Dion, fondateur de Relations industrielles/Industrial Relations, fut un digne représentant.

4 Hyman, Richard. 2009. «Why Industrial Relations? », What's the Point of Industrial Relations?, sous la direction de R. Darlington, Manchester, BUIRA.

5 Rodgers, Daniel. 2011. Age of Fracture, Cambridge, Massachusetts, The Belknap Press of Harvard University.

6 Arthurs, Harry. 2006. "What Immoral Hand or Eye?: Who Will Redraw the Boundaries of Labour Law », Boundaries and Frontiers of Labour Law: Goals and Means in the Regulation of Work, sous la direction de Guy Davidov et Brian Langille, Oxford, Hart Publishing, 373- 
389; Arthurs, Harry. 2011. "Labour Law After Labour ", The Idea of Labour Law, sous la direction de Guy Davidov et Brian Langille, Oxford, Oxford University Press, 13-29.

7 Whitfield, Keith et George Straus. 2000. « Methods Matter: Changes in Industrial Relations Research and their Implications », British Journal of Industrial Relations, 38 (1), 141-151.

8 Association canadienne d'Études du Travail et du Syndicalisme (ACETS), http://cawls.ca/fr/ (11 janvier 2014).

9 Je développe cette idée plus en détail dans Arthurs, Harry. 2013. "Labour Law as the Law of Economic Subordination and Resistance: A Thought Experiment », Comparative Labor Law and Policy Journal, 34, 585-604.

$10 \mathrm{NdT}$ : En français dans le texte.

$11 \mathrm{NdT}$ : En français dans le texte.

12 Rodgers, Daniel. 1998. Atlantic Crossings, Cambridge, Massachusetts, The Belknap Press of Harvard University, p. 413-416. 